Journal

of Geography

Politics and Society

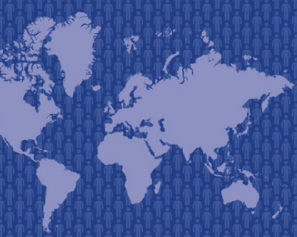

$9(4) / 2019$

\section{Journal of Geography, Politics and Society}

2019, 9(4), 58-66

https://doi.org/10.26881/jpgs.2019.4.07

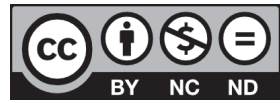

\title{
SPECIFIC ASPECTS OF EUROPEAN AND POLISH MIGRATIONS AT THE BEGGING OF THE 21ST CENTURY
}

\author{
Jarosław Och \\ Institute of Political Sciences, Faculty of Social Sciences, University of Gdańsk, Bażyńskiego 4, 80-309 Gdańsk, Poland, ORCID: 0000-0003-0771-2732 \\ e-mail: jaroslaw-och@wp.pl
}

\section{Citation}

Och J., 2019, Specific aspects of European and Polish migrations at the begging of the 21 st century, Journal of Geography, Politics and Society, 9(4), 58-66.

\begin{abstract}
The text focuses on the migration in the European Union and in Poland at the begging of the 21st century. It aims to prove that even if the reasons and consequences of migration are varied, they have significantly shaped the development of human civilization and have been a part of human socialization. Furthermore, this text points out that the phenomena of globalization and democratization have affected the population movement and caused new patterns of contemporary migration. The European Union is a great example of cooperation between different countries in order to realize the principle of free population movement, which was put to the test over past years. Additionally, this article characterizes the Polish migration, especially the inflow of immigrants to Poland. Poland has become an emigration and an attractive immigration country. This text revels also the consequences of migration in modern Europe.
\end{abstract}

\section{Key words}

migration in Europe, European Union, migration, polish migration, population movement.

Published: 31 December 2019

\section{Introduction}

Population migration is a phenomenon that has been a part of human history since the dawn of time (see more: Zamojski (ed.), 2002). It is a sign of openness to the world, entrepreneurship, courage, risk in decision-making and adaptation to the changing reality. It is seen as a relict of nomadic, or even colonial behavior.

Migrations have become the essential component and agent of intercultural and interpersonal relations in the world. They have impacted the political and socio-cultural state of world. Migration processes have been a part of human socialization, which not only led to geographical changes, but also quite significantly shaped the development of human civilization (Barbag, 1978).

The extent of migration and their institutional forms were significantly dependent on the level of development of civilization, particularly on the state of technical progress. In fact, two of the fundamental determinants for migrations were the geographical, and economic conditions of the state.

Migrations at the begging of the 21st century have been characterized by a new quality. The political, economic and social factors have determined 
the new speciality in terms of destination, duration and motivations. The process of democratization and globalization has significantly impacted the contemporary migrations in Europe.

Democratization means universalization of civil rights and freedoms, including the right to freely move and decide on the choice of residence. That primarily means the peaceful coexistence of countries and undertaking actions to empower citizens (Dahl, 1995). The experiences from the 19th and 20th centuries irrefutably show that embedding state in the democratic regime positively influences the observance of civil rights, as well as facilitates the decision about migration (Baszkiewicz, 1999; Grabowska, Szawiel, 2003). Democratic world also ensures peace, that affects correct international relations and leads to agreements. These agreements often go far beyond the standard cooperations between countries (see more: Nakonieczna, 2007). An example of this type of agreement is the European Union, whose supporting pillar is the principle of democratic functioning of the Member State. A characteristic feature of the EU internal cooperation is the principle of free population movement within the territory of the Member States (Stępniak (ed.), 2001).

Globalization is a political, social and economic phenomenon, which implies a new perception of the world. That means closer interrelationship among the countries, nations and different part of the world that has become a global village. As one of the mega trends of contemporary world, significantly influenced the migration by creating its new patterns. This process caused the intensification of migration movements and massive social activities that encourage to live in better, richer and fully selfdeveloped environment (Bauman, 2002). Moreover, it has integrated the world economy and social sphere.

The changes within political, economic or social sphere at the begging of the 21 st century have transformed the migration process. They significantly impacted the population movements on the European scale, including Polish migrations. Referring to the characteristics of migration streams in the European Union, efforts are being made to systematize knowledge about Polish migration movements.

\section{Contemporary migrations within the European Union}

The phenomenon of migration has shaped the image of current European Union. Migration flows over past years within and outside of the EU have impacted the current population structure in the
Member States. The EU faces two types of migration: the intra-EU migration for the purpose of employment, of studying or for a family reasons and the migrations from outside the EU states. Since 2015, the EU has faced the migration crisis and immigration flows from Africa and Ukraine which significantly put the migration policy into a test and even questioned the power of integration. The new arrivals could partly solve the labour market shortages, but do not reverse the ongoing process of aging population in Members States, even though they have had a strong impact on the population structure.

In 2000, one of the fundamental European values, which is the principle of free movement was included in the Charter of Fundamental Rights of the European Union adopted in Nice, on December, 8 2000. In accordance with article 45 of the CFR every citizen has a right to freely move and reside within the territory of the Member States (Charter of..., 2000). One of the most important regulations concerning a freedom of movement for workers were included in primary Community law, in article 39-42 of the Treaty of European Community (Mitrus, 2003) and Schengen Agreement.

Firstly, according to the most important art. 39 of the Treaty establishing the European Community (Treaty establishing..., 2002):

1. Freedom of movement for workers shall be secured within the Community.

2. Such freedom of movement shall entail the abolition of any discrimination based on nationality between workers of the Member States as regards employment, remuneration and other conditions of work and employment.

3. It shall entail the right, subject to limitations justified on grounds of public policy, public security or public health:

a) to accept offers of employment actually made;

b) to move freely within the territory of Member States for this purpose;

c) to stay in a Member State for the purpose of employment in accordance with the provisions governing the employment of nationals of that State laid down by law, regulation or administrative action;

d) to remain in the territory of a Member State after having been employed in that State, subject to conditions which shall be embodied in implementing regulations to be drawn up by the Commission.

4. The provisions of this article shall not apply to employment in the public service.

The specific rules concerning the freedom of movement for workers were included in communities acts, which are a part of secondary law. The most 
important are regulations and directives. The first ones are uniform and entirely applied to all EU members, the second ones are firm to achieve a certain result, but leave members free to choose how to do so. There are few significant regulations and directives, which impact on a freedom of movement for workers:

- the restrictions on freedom of movement and citizens residence in the Members State, justified on public order and security or public health care;

- the freedom of movement for workers in the EU;

- the abolition of restrictions on the right of EU citizens and their families to move and reside freely within the EU;

- the right of workers to remain in the territory of a Member State after having been employed in that State;

- the appliance of social security system for employed persons, self-employed persons and their families members living in the Community;

- the recognition of the academic diplomas obtained after the professional education and at least three years formation;

- the right of residence for employees and selfemployed persons who have ceased their occupational activity;

- the posting of the workers as a part of providing services;

- the safeguarding the supplementary pension rights of employed and self-employed persons moving within the Community.

Above these acts, there are also different directives which go beyond the issue of free movement, but are relevant to broadly understood this freedom:

- the abolition of restrictions on movement and residence within the Community for nationals of Member States with regard to establishment and the provision of services;

- the right of residence (right of residence in other Member State, than home country for Union citizens who can finance their residence);

- the right of residence for students;

- about exercising the right to vote in European Parliament election

- about exercising the right to vote and right to stand as a candidate in local elections for citizens of the Union residing in a Member State of which they are not nationals.

All these regulations are intended to remove obstacles to the liberalization of free movement of persons within the EU. The European Court of Justice judgments took an extremely active part in this process. The issues of the free movement and residence for EU citizens are stated in the European Constitution project. The article 45 reveals that every citizen of the Union shall have the right to move and reside freely and article III-18 every worker have a right to freely move in the European Union.

Secondly, the adoption of Schengen agreement was an essential factor, which conditioned the implementation of free movement of persons within the EU. Since 2007, it strongly affected the Polish migration policy. The content of this agreement contains:

- the unitary system of crossing the external borders;

- the harmonization of visa policy, common policy towards the foreigners from third countries;

- the common criteria and mechanism concerning the asylum procedures, in particular which Member State is responsible for examining an asylum application;

- the police cooperation rules and measures;

- the improvement of legal assistance on criminal and extradition matters;

- the cooperation against illicit drugs;

- the common regulations on the possession and trafficking weapons and ammunition;

- the creation and functioning rules of Schengen Information System (Jaworski (ed.), 2001).

The freedom of movement for workers in the EU is one of the fundamental European freedoms. Nevertheless, it might presents particular tensions between Members States. The unrestricted intra-EU migration and equal access to national welfare states have been a challenge for certain MS and created an arguable debate about the reforming free movement. The UK mainly insisted on changing the mobility policies and recognizing the UK as a "special case" that was not achieved by British government. This contention was a major factor in the UK's recent referendum vote to leave the EU (see more: Ruhs, 2017).

Besides the disagreements on the political level, the vast majority EU workers benefited from the right to freely move and reside in the EU, especially after flexibilization of European labour market.

There have been four main phases in the European migration, which are closely linked to history, economic development, demographic changes, the transformations of labour market and the processes of EU enlargement. The first phase lasted from 1945 to 1970 , then the second phase mid-1970-mid1990 and the phase mid-1990-2008. The four phase started in 2008 and is ongoing. In raport published by European Commission in 2018, this four phase is characterized by consolidation and stabilization of intra-EU migration and a high immigration of nonEU citizens (European Migrations..., 2018). 
The EU has adopted frameworks to manage legal migration flows for highly skilled workers, students, seasonal workers and family reunification. In order to attract talented workers even outside the $\mathrm{EU}$, the blue card directive was adopted in 2009. There is also a set of rules for resettlement of refugees that was launched in July 2015 (How the EU..., 2019).

The statistics concerning the migration outside the EU show that migrations to EU countries declined between 2007 to 2012. It reflected the domestic migration, which decreased at the same time (Internatioanl..., 2011). Starting in 2012, and particularly since 2015 , both intra-EU and extra-EU migrations have rebounded, mainly as a result of resumed economic growth and boost of employment. According to European Commission's raport in 2015 total intra-EU migration was 1.4 million while total legal migration from non-EU countries was 2.4 million. Romania and Poland were the most important origin countries for intra-EU migration, whereas Ukraine and Syria have risen as main non-European origin countries (European Migrations..., 2018). Since 2015, migration debate was mainly dominated by flows of Syrian and other refugees entering from Turkey, Greece and Italy. In 2015, almost 1.3 million asylum seekers came to Europe, with Syrians and Afghans nationality. In 2015 and 2016, an estimated total of 1.2 million people arrived in Germany to ask for asylum (Labour... 2017). Since the 2016 these applications have decreased while the border controls have increased (European Migrations..., 2018).

As of December, 2019, 125.0 arrivals came to Europe, including 101.7 by sea and 23.3 by land. One year earlier the number of arrivals was more than two times smaller comparing with the data from 2016. The number sharply decreased from 390.4 in 2016 when the migration flow was on the massive scale to 144.1 in 2018 (Flow Monitoring Europe). This decreasing number was a result of adopted European migration policy and border control. At that time, migration scholars have done researches on significant, sometimes even negative immigration impact on the local and national culture. Migration policy should include the effective tools, which will facilitate the integration and assimilation processes in the society.

The flows of migration impacted the European population over past years. On January, 12018 the population of the EU-28 was estimated at 512.4 million. Young people ( 0 to 14 years old) made up $15.6 \%$ of the EU-28's population, while persons of working age (15 to 64 years old) accounted for $64.7 \%$ of the population. Older persons (aged 65 or over) reached $19.7 \%$ (an increase of 2.6 percentage points compared with 10 years earlier) (Migration and..., 2019). Belgium, Ireland, Cyprus, Luxembourg, Malta, the Netherlands, Austria, Romania, Slovakia and the United Kingdom were the only EU Member States where non-nationals were mainly citizens of another Member State. In most MS, the majority of non-nationals were citizens of non-EU countries. Luxembourg was a state with the highest share of non-nationals, non-nationals accounted for $48 \%$ of its total population. In contrast, in Poland and Romania non-nationals represented less than $1 \%$ of the population. According to Eurostat data, the half of immigrants were aged under 28 years. The median age of the total population of the EU-28 stood at 43.1 years, while it was 28.3 years for immigrants to EU-28 in 2017 (Migration and..., 2019).

The aging population in EU countries has become an alarming fact, which shape the future of the EU. The population aged 65 years and over is increasing in every EU Member State, EFTA country and candidate country. Eurostat published set of population projections covering the period from 2018 to 2100. The EU-28's population will probably increase to a peak of 525.0 million around 2040 and thereafter gradually decline to 492.9 million by 2100 . During the period from 2018 to 2100 the population of working age is expected to decline until 2100, while those aged 65 years and over are likely to increase to account for $31.3 \%$ of the EU-28's population by 2100 , compared with 19.8\% in 2018 (Population structure and aging, 2019). Moreover, Eurosat's data inform that there will be 66.1 million of people aged 80 years and over by 2080 (People in the EU..., 2017). These numbers prove that the group of people of working age is shrinking while the relative number of those retired is expanding. It will lead to a transition towards a much older population and a deep change in social policy.

This phenomenon of aging Europe may be explained by the law fertility rate and advanced medicine and healthcare. The recent data published by Eurostat in 2019 have shown that the European fertility rate in 2017 was 1.59 and the mean age of women at birth of first child was 29.1 years. France was the Member State with the highest total fertility rate in the $\mathrm{EU}$, the result was 1.90 births per woman (Births and fertility..., 2019). In Poland this trend is quite similar. In 2017 total fertility rate was amounted to 1.45 and aged of women with the first brith was 28 years (Sytuacja..., 2018). As the result of consistently low birth rates and higher life expectancy, the shape of the EU-28's population structure is transforming. The government of several Member States being aware of situation, decided to promote the procreation attitudes by giving: tax breaks for parents, paid parental leave, free childcare, financial 
support. However, these initiatives have not brought the expected results. Despite the immigration flow entering the labour market, the situation did not effectively solve the problem of aging population. The reasonable solution to change it, should be the implementation of programs to increase the birth rate, and to attract the immigrants at once (see more: Rifkin, 2005).

If this demographic reality of Europe does not change, Europe will be losing its civilizational vitality. It would cause not only population issues but also economic and financial problems, because less people will pay the taxes, from which the pensions are financed. New migration patterns, especially the waves of arrivals from non-EU countries have shaped the European civilization. The contemporary migration movements in Europe revel that they are an important power, transforming cultural and social order within the EU. Furthermore, they have influenced the social and migration policy managed by Member State. Since the EU includes 28 countries until Brexit, there is a significant need of efficient solidarity to face the contemporary, European challenges, which should lead to human and civilizational development.

\section{Migration patterns in Poland at the begging of 21 century}

The period at the turn of the 20th and 21st centuries was the time of Poland political changes and proces of democratization. After 1989, the remarkable period in Polish history was the time of accession negotiations to European structures and attainment of full-fledged membership which was concluded in May, 1 2004. This historical moment opened the door to new dimension of Polish migration and its new forms (Wiśniewski, Duszczyk, 2006). The opening of the EU's labor market and fluid mobility within the EU caused an emigration renaissance to the EU countries. Poland as the EU Member State participates in policy making on migration and implements the EU directives to facilitate the integration.

Since 2004, the year of Poland's accession to the $\mathrm{EU}$, Poles have been eager to migrate within the Union. Polish citizens are the second nationality among the biggest groups of EU-citizens living in other MS in 2018 (Migration and migrant population..., 2019). After the accession, the access to the labor market was open and very attractive for Polish workers. The United Kingdom, Ireland and Sweden gave straightaway this possibility for the Eastern and Central European new Member States. The full labour rights immediately granted by the UK caused the high level of Polish migration. The year of 2011 revealed around 2.1 million temporary migrants, of whom 611.0 were living in the UK, 466.5 of these had stayed in Great Britain for at least one year. Overall, from May, 12004 to December, 31 2012, the number of Polish migrants reached between 573.0 and 588.0 (Okólski, Salt, 2014).

Nevertheless, Poland has become an emigration and immigration country. According to the recent International Migration Outlook 2019, emigration of Poles to OECD countries decreased by 5.7\% to 248.0. $60.3 \%$ of people migrated to Germany, $10.1 \%$ to the United Kingdom and 9.6\% to the Netherlands (International..., 2019). However, in 2014 the wave of immigration from Ukraine began in Poland. In 2017 Poland became a leader in the inflow of foreign, seasonal, short-term workforces (International..., 2018).

The Office for Foreigners has observed that the inflow of foreigners to Poland considerably increased since 2014. Few factors caused this immigrant flow to Poland. The internal agents such as the liberalization of visa regime and the simplification of procedures for foreigners in Polish law took an important role in attracting foreign citizens to Poland. In 2015 there was a significant legal change in the employment of foreigners in Poland. The system of work statement was applied, which allows to carry out a job by foreigner for up to six months within a 12-month period. In 2017 the new regulations concerning the visa-free regime for Ukrainian citizens with biometric passports came to force. It entitles to tourist, family and business stay but does not allow to work. The temporary stay are strongly dominant, even 10 times more demanded than the applications for permanent stay. Economic immigration to Poland is particularly the most popular, around 73\% in 2018 (Raport na temat..., 2019). All this changes attracted foreigners, especially the Ukrainians to come to Poland. The external agents such as the annexation of Crimea in March 2014 and the outbreak of the conflict in Donbass in 2014 influenced the political, social and economic situation in Ukraine. As the results, the sharp economic recession was triggered by these events, which was followed by the immigrant flow. The largest inflow of Ukrainians regarding the number of employer's declarations for short-term work and work permits was the highest between 2014 and 2016 (Jaroszewicz, 2018).

There was an evolution of first residence permits in the EU, where Poland took a significant place. In 2018 above 3 million residence permits was issued to non-EU citizens. The number increased by $0.4 \%$ compared with 2017 and it continues the upward. Among the reasons, the family reason was the most popular (28\%). Then, employment accounted for 
$27 \%$, education reasons for $20 \%$ and international protection for $24 \%$. In the EU, the highest number of residence permits for Ukrainians was issued in Poland (635.0, or $20 \%$ of total permits issued in the EU), followed by Germany 17\%, United Kingdom 14\% and France $8 \%$. In Poland $37 \%$ of all permits was issued for employment (First residence permits..., 2019).

The immigrants have an intention not only to stay but often also work in Poland. In 2018 the Ministry of Family, Labour and Social Policy has published the raport about of immigrant employment in Poland. The number of work permit is significantly growing. This publication shows that in 2017 the number of issued work permit was 235,626 , in 2018 it was 328,768 . In current year 2019 the number for the first half a year accounted for 217,297 , which is impressive comparing with the first half of 2018, when the number reached 147,981 . It has been estimated that Poland has become an interesting country not only for temporary stay, but also for daily work and life. The perfect example is the number of Ukrainians. According to data from 2018 published by MRPIPS (Polish Ministry of Ministry of Family, Labour and Social Policy) the amount of work permit for the Eastern neighbor was 238,334 which was only 100.0 less than the total number. In the first half of 2019, they received 162,421 work permits, which was around the $3 / 4$ of the annual number (Zezwolenia na..., 2019). They are also the biggest around $30 \%$ group among unemployed. However, considering the duration of stay in the register of unemployed, foreigners were less often long-standing group than Poles (Informacja o zatrudnieniu..., 2018). Among the immigrants from Ukraine, the dominance of men as well as the young people is definitely visible (Raport na temat..., 2019).

It has to be admitted that the Ukrainian workers has become a valuable employees on the European market. As the results, Polish employers are facing a strong competitive pressure from Germany, Czech Republic and Hungary, where the labour market is more and more open and advantaged for them, especially in the term of better salaries. Besides, the huge amount of Ukrainian workers on the Polish labour market, there is an inflow of workers from Asia. According to the raport of Ministry of Ministry of Family, Labour and Social Policy, over 35 thousand of work permits were issued for Asians. It is $42 \%$ more than the previous year. In the first six months of 2019, most of those permits were granted to over 6 thousand Nepalese and over 4 thousand Indians. There is an inflow of people from Moldova and Kazakhstan (Zezwolenia na..., 2019). These numbers may suggest that Polish employers would favorably turn towards the Asian employees in future. The foreign workers are needed and this phenomenon of immigration flow will continue to keep the Polish economy growing.

Poland has become an attractive country for immigrants, but there is also a significant change in the amount of Polish emigrants, which characterizes the contemporary Polish migration pattern. According to data published by Statistic Poland, 2018 was the first year since eight years, in which the number of Polish immigrant declined in other countries, mainly in Great Britain and Italy. The most significant changes have been noticed in this first country, where the number of Polish emigrants for a temporary stay decreased of 98 thousand. It means that more people left this country than arrived. Those who left Great Britain, decided to returned to Poland or moved to the other country. The statistic has estimated that at the end of 2018 around 2.455 thousand permanent residents of Poland temporary stayed abroad, which is $3 \%$ less than in 2017. Around 2.031 thousand Poles resided in the EU countries, mostly in Germany, Great Britain, Netherlands and Ireland (Informacja o rozmiarach..., 2019). Two factors affected this decrease. Firstly, a good situation of Polish labour market, low unemployment and an increase standard of living attracted Polish emigrants. Secondly, the uncertain political situation of Great Britain related to Brexit.

Poland, supporting by European Commission, is developing a migration strategy for next years to face the issue of an aging population, a growing labour demand and emigration of young citizens. The main aim is to sustainable labour migration policy framework encouraging the return of Polish emigrants, enhancing the bilateral cooperation and foster integration and assimilation of immigrants. In January and February 2018, the amendments to the Act on Employment Promotion and Labour Market Institutions and the Act on Foreigners took effect. The EU directives which facilitate the recruitment of foreign workers came into force. Currently, all foreign residents are provided a comprehensive integration support, as well as free language and cultural adaptation courses. The provincial governors in cooperation with NGOs, with co-funding from the EU Asylum, Migration and Integration Fund have been implemented the projects, facilitating the integration. From 2019, holders of a permit granting labour market access have a possibility to ask for housing allocations under the "Flat for Start" program (International..., 2019).

Additionally, Poland has become very common destination for international student and their interest is growing. Around 65.8 international student were enrolled in Poland for academic year 2016/2017, 
an increase of $15 \%$ over the year. They represented about $5 \%$ of total university student population. The number of foreign student was increasing over the past years. Internationalization of Higher Education in academic year 2010/2011 was 1.12, in 2016/2017 the number was four times higher and reached 4.88 (Migration statistics..., 2018).

Over past few years, there is an increase in number of foreigners coming to Poland, particularly for work. The Polish labour market has become various and open to other nationalities. The law measures has been taken to facilitate work and daily life of immigrant in Poland. However, Polish market has to compete with other European country. One the one hand, it might pose an obstacles and hire the immigration flow to Poland, but on the other hand it might lead to improvement of migration policy, included in labour and social policy. The number of 200 thousand working Ukrainians has revealed that they are eager to work in Poland. They can feel well integrated in Polish society because of history, culture and language similarities. The Polish government and society have to take the initiatives to assimilate the foreigners to keep this tendency of high immigration flow. Apart from, the openness of Polish policy towards immigrants, Poland has to take actions in order to keep Polish citizens in the country and attract the Polish emigrant to return to their country of birth.

\section{Conclusions}

The analysis of contemporary migration movements in the EU at the begging of 21 century revels that they are an important power, transforming population structure, influencing economy, political and cultural order. There are different types of migration: the short time stay, shuttle stay, transit migration and war migration, each of them has an impact on the society. The EU faced few migration flows which allowed to study the short- and long-term consequences of open border regimes on population movement. One of the biggest internal migration pattern was the time after the EU enlargement. Since 2015 , the external migration flows have been a challenge for common European migration policy and in broad term for the idea of integration. Migration from non-EU countries has also influenced the Poland, its migration policy and has shaped the Polish society. Poland has been one of the main countries for intra-EU migration since the Eastern enlargement. Over past few years this MS has become an interesting destination for immigrants. Poland has adjusted their migration policy to changing reality, and has faced the same dilemmas, as the rest of EU Members.

Democratization and globalization phenomenon made the migrations easier and massive within the EU, however it also caused political and social issues. These two processes led to tied and effective cooperation of the EU Member State in order to bring closer the citizens to each other. As the effect, new tendencies have been noticed in the European migration reality, which shaped the human development and European civilization, as well the European contradictions occurred. Due to new migrations patterns, new multiethnic and multicultural communities have emerged in societies. In these new realities the axiological order has changed and its process of unification has proceeded. Contemporary migrations have caused the positives and negatives aspects occurring in every country of European Union.

Migration has brought positive element enriching the EU. The short time migrations have allowed the EU citizens to gain the financial sources, educational or life experience and come back to country of birth. The long time migrations led to move the EU workers to the country where he or she is needed in order to solve the labour market shortages. It also makes the wish of living abroad possible and easier. The EU migration policy aims also to the non-EU citizens, so that they could benefit from the European values too and impact the European civilization. The European migration policy based on immigrant openness leads to putting the European and human values into practice by: respecting international law related to human, reinforcing modern education, tolerance, coexistence of different cultures and subcultures, as well as cultural and civilization syncretism.

At the same, the issue of freedom of immigrant has been reveled. There is a contradiction between declared freedom of immigration and its reality, which is restricted, internationally controlled and stimulated by state. The selective choose of immigrants by countries is strongly visible. The immigrants, who can bring visible profits to receiving country, are well accepted, in contrast to the immigrants, who cannot adapt themselves to modern values. This situation leads to stressful conflicts, tensions and Europeans ethical dilemmas. The repeated references to the mythological reality about all migrants or only particular groups in a stereotypical way are present in European societies. This phenomenon could be positive, but also negative for immigrants. On the one hand, there is an understanding and support of state and European authorities, on the other hand, there is an increasing number of distrustful, racial and xenophobic attitudes in societies. As the results, the bipolarization of cultural and civilizational life is present 
in current societies. On the one side, there are decisive, courage, entrepreneurial and creative people, active individuals who profit from migration. On the other side, there are "excluded individuals" who cannot adapt to fast changing cultural reality, they feel alienated and struggle with finding a their place in new social sphere. By joining the Union, Member States have agreed to pursue a common enterprise, at the same they have also accepted considerable risks: they have opened up their markets and their societies on the migration flows. However, in political debates on free movement rights receiving countries tend to leave the social costs of free movement for sending countries aside (Seuber, 2019).

The analysis of the massive population movement show that immigrants can create the specific cultural dispersion in country of destination, in which they are not willing to assimilate. They would try to create a multidirectional loyalty, it means that the immigrants identify with both, the country of origins and emigration country. It would also mean the necessity to redefine the term "homeland", which from a geographic meaning will change into an emotional connection. The national identification would be no more linked with specific territory, but turn into a state of migrant's mind. The awareness of changes occurring in new migration patterns should be a subject of deep interest, in every countries, which received the immigrants, as it could lead to serious religious, national and ethic conflicts. It has already raised the question about European integration and strength during the migration crises. Migration might strongly transforms the society structure and social mentality which lead to human development. It is an element interfering the intercultural and interpersonal relations in the world. However, the ignorance of migration effects could have a negative impact on the human development and European civilization.

\section{Reference}

Barbag J., 1978, Geografia polityczna ogólna (Eng. General political geography), PWN, Warszawa.

Baszkiewicz J., 1999, Władza (Eng. The authority), Ossolineum, Wrocław.

Bauman Z., 2000, Globalizacja. I co z tego wynika dla ludzi (Eng. Globalization. And what does it mean for people?), Państwowy Instytut Wydawniczy, Warszawa.

Births andfertilityover 5 milion in EU in 2017,2019, Eurostat, https://ec.europa.eu/eurostat/documents/2995521/ 9648811/3-12032019-AP-EN.pdf/412879ef-3993-44f58276-38b482c766d8 (accessed 30 December 2018).
Charter of Fundamental Rights of the European Union, 2000, European Parliament, https://www.europarl.europa.eu/ charter/pdf/text_en.pdf (accessed 20 November 2019).

Dahl R., 1995, Demokracja i jej krytycy (Eng. Democracy and its critics), Wydawnictwo Znak, Kraków.

European Migrations dynamics, drivers and the role of policies, 2018, European Commission, https://publications. jrc.ec.europa.eu/repository/bitstream/JRC109783/kjna29060enn.pdf (accessed 28 December 2019).

First residence permits issued in the EU Member, States remain above 3 million in 2018, 2019, Eurostat, https://ec.europa. eu/eurostat/documents/2995521/10189082/325102019-AP-EN.pdf/95e08bc8-476d-1f7d-a519300 bdec438cb (accessed 11 December 2019).

Flow Monitoring Europe, International Organization for Migration, https://migration.iom.int/europe?type=arrivals (accessed 11 December 2019).

Grabowska M., Szawiel T., 2003, Budowanie demokracji (Eng. Building democracy), PWN, Warszawa.

How the EU manages migration flows?, 2019, European Council, https://www.consilium.europa.eu/en/policies/migratory-pressures/managing-migration-flows/ (accessed 10 December 2019).

Informacja o rozmiarach i kierunkach czasowej emigracji z Polski w latach 2004-2018 (Eng. Main direction and size of temporary emigration from Poland in 2004-2018), 2019, Główny Urząd Statystyczny, https://stat.gov.pl/obszarytematyczne/ludnosc/migracje-zagraniczne-ludnosci/ informacja-o-rozmiarach-i-kierunkach-czasowej-emigracji-z-polski-w-latach-2004-2018,2,12.html (accessed 10 December 2019).

Informacja o zatrudnieniu cudzoziemców w Polsce (Eng. Information about immigrant employment), 2018, Ministerstwo Rodziny, Pracy i Polityki Społecznej (accessed 30 November 2019).

International Migration Outlook 2011: SOPEMI, 2011, OECD, https://www.oecd.org/migration/48342373.pdf (accessed 11 December 2019).

International Migration Outlook 2018, 2018, OECD, https:// read.oecd-ilibrary.org/social-issues-migration-health/ international-migration-outlook-2018_migr_outlook2018-en\#page1 (accessed 11 December 2019).

International Migration Outlook 2019, 2019, OECDiLibrary, https://www.oecd-ilibrary.org/sites/c3e35eec-en/1/1/1/ index.html?itemld=/content/publication/c3e35eecen\&mimeType=text/html\&_csp_=5484c834d3b947b42e 43a8aee995b48b\&itemIGO=oecd\&itemContentType=bo ok (accessed 11 December 2019).

Jaroszewicz M., 2018, Migration from Ukraine to Poland the trend stabilises, Ośrodek Studiów Wschodnich im. Marka Karpia, Warszawa, https://www.osw.waw.pl/sites/default/ files/Report_Migration\%20from\%20Ukraine_net.pdf (accessed 30 November 2019).

Jaworski P. (ed.), 2001, Polska droga do Schengen. Opinie ekspertów (Eng. The Polish way to Schengen. Expert opinions), Instytut Spraw Publicznych, Warszawa.

Labour Market Integration of Refugees in Germany, 2017, OECD, https://www.oecd.org/els/mig/Finding-their-WayGermany.pdf (accessed 11 December 2019). 
Migration and migrant population statistics, 2019, Eurostat, https://ec.europa.eu/eurostat/statistics-explained/pdfscache/1275.pdf (accessed 11 December 2019).

Migration statistics in Poland data and methodology, 2018, Statistics Poland, http://www.instat.gov.al/media/3875/ konf_migracioni_statstics-poloni.pdf (accessed 11 December 2019).

Mitrus L., 2003, Swoboda przemieszczania się pracowników po przystapieniu Polski do Unii Europejskiej (Eng. Freedom of movement for workers after Poland's accession to the European Union), LexisNexis Polska, Warszawa.

Nakonieczna J., 2007, Migracje międzynarodowe a rozwój państwa (Eng. International migration and state development), Scholar, Warszawa.

Okólski M., Salt J., 2014, Polish Emigration to the UK after 2004; Why Did So Many Come?, Central and Eastern European Migration Review, 3(2), 11-37.

People in the EU - population projections, 2017, Eurostat, https://ec.europa.eu/eurostat/statistics-explained/index. php/People_in_the_EU_-_population_projections (accessed 5 November 2019).

Population structure and aging, 2019, Eurostat, https:// ec.europa.eu/eurostat/statistics-explained/index.php/ Population_structure_and_ageing\#Past_and_future population_ageing_trends_in_the_EU (accessed 10 December 2019).

Raport na temat obywateli Ukrainy (Eng. Raport on the citizens of Ukraine), 2019, Urząd do Spraw Cudzoziemców, https://udsc.gov.pl/statystyki/raporty-specjalne/biezacasytuacja-dotyczaca-ukrainy/ (accessed 11 December 2019).

Rifkin J., 2005, Europejskie marzenie (Eng. European dream), Wydawnictwo Nadir, Warszawa.

Ruhs M., 2017, Free Movement in the European Union: National Institutions vs Common Policies?, International Migration, 55(S1), 22-38. doi:10.1111/imig. 12398.

Seuber S., 2019, Shifting Boundaries of Membership: The politicisation of free movement as a challenge for EU citizenship, European Law Journal. doi: 10.1111/eulj.12346 (Online Version of Record before inclusion in an issue)

Stępniak A. (ed.), 2001, Swobodny przepływ pracowników w kontekście wejścia Polski do Unii Europejskiej (Eng. Free movement of workers in the context of Poland's membership in the European Union), UKIE, Warszawa.

Sytuacja demograficzna Polski do 2017 r. Urodzenia i dzietność (Eng. Demographic situation in Poland up to 2017 Births and fertility), 2018, Główny Urząd Statystyczny, Warszawa.

Treaty establishing the European Community (Consolidated version 2002), 2002, https://eur-lex.europa.eu/legal-content/ EN/TXT/?uri=CELEX\%3A12002E\%2FTXT (accessed 17 November 2019).

Wiśniewski J., Duszczyk M., 2006, Migracje zarobkowe Polaków po 1 maja 2004 r. (Eng. Economic migrations of Poles after the 1 of May 2004), Instytut Spraw Publicznych, Warszawa.

Zamojski J.E. (ed.), 2002, Migracje. Historia i Kultura. Migracje iSpołeczeństwo, T.7 (Eng. Migrations. History and Culture. Migrations and Society, vol. 7), Neriton, Warszawa.
Zezwolenia na pracę cudzoziemców (Eng. Work permit for foreigners), 2019, Ministerstwo Rodziny, Pracy i Polityki Socjalnej), https://psz.praca.gov.pl/web/urzad-pracy/-/8180075-zezwolenia-na-prace-cudzoziemcow (accessed 10 December 2019). 